\title{
KONSTRUKSI KALIMAT PADA DIALOG FILM HAFALAN SHALAT DELISA KARYA TERE LIYE
}

\author{
Puronami Sarah Stefany ${ }^{1 *}$, Made Sri Satyawati ${ }^{2}$, dan Anak Agung Putu Putra ${ }^{3}$ \\ 1,2,3) Universitas Udayana \\ *) Posel: butarbutarfany@gmail.com \\ Artikel dikirim: 15 Juli 2021; Diterima: 14 Agustus 2021

\section{SENTENCE CONSTRUCTION IN THE DIALOGUE OF HAFALAN SHALAT DELISA FILM BY TERE LIYE}

\begin{abstract}
This research is entitled "Konstruksi Kalimat Pada Dialog Film Hafalan Shalat Delisa Karya Tere Liye". This study aims to describe (a) the structure of the sentence and (b) what types of sentences are used in the dialogue. The data collection methods and techniques used are the note-taking method, data analysis methods and techniques using the agih method with basic techniques for direct elements, while the methods and techniques for presenting the results of data analysis are formal methods with descriptive techniques. The results of this study include the structure of sentences in the dialogue of the film Hafalan Shalat Delisa which is divided into two groups, namely the structure of single sentences and compound sentences. The single sentence structure consists of eight sentence patterns, namely (1) SP, (2) SPO, (3) SPK, (4) SP-Pel, (5) SPOK, (6) SPO-Pel, (7) PK, and (8) $\mathrm{PO}$. In compound sentences there are five sentence patterns, namely (1) SP+SP, (2) SP+PO, (3) $\mathrm{SP}+\mathrm{PK},(4) \mathrm{Konj}+\mathrm{SPO}+\mathrm{KSP}$ and (5) SPPel+SPO. The types of sentences in the film dialogue Hafalan Shalat Delisa are divided into three types, namely (a) types of sentences based on the number of clauses, namely single sentences, equivalent compound sentences, multilevel compound sentences and mixed compound sentences, (b) types of sentences based on syntactic classification in the form of declarative sentences, imperative sentences, interrogative sentences, and exclamatory sentences, and (c) types of sentences based on the completeness of their elements in the form of major sentences and minor sentences.
\end{abstract}

Keywords: syntax, sentence structure, and sentence types

\section{PENDAHULUAN}

Film Hafalan Shalat Delisa merupakan film yang diadaptasi langsung dari novel karya Tere Liye. Novel ini merupakan novel karya Tere Liye yang terlaris dari karya-karya lainnya. Kisah inspiratif tentang keluarga dalam isu besar tsunami di Aceh menyebabkan novel ini laris dan dikenal secara internasional. Sajian film ini sangat sederhana dan pilihan bahasa yang dipakai merupakan bahasa lisan yang umum digunakan sehari-hari. Jika dilihat dari segi tata bahasa, bahasa yang digunakan berbeda dengan bahasa yang standar, baik dilihat dari pilihan kata maupun dari struktur atau pola urutan kalimat. Konstruksi kalimat yang berbeda tersebut merupakan suatu fenomena bahasa yang menarik untuk diamati. 


\section{STILISTIKA}

Seperti yang kita ketahui bersama bahwa bahasa merupakan media berkomunikasi yang bersistem. Sistem komunikasi ini disusun oleh bunyi-bunyi bahasa untuk membangun satuan yang lebih besar seperti morfem, kata, dan kalimat (Richards, Platt \& Weber, 1985: 153). Sebagai alat komunikasi, bahasa terorganisasi dalam bentuk satuan-satuan seperti kata, kelompok kata, klausa dan kalimat yang diungkapkan, baik secara lisan maupun tulisan. Organisasi bahasa ini menyebabkan setiap komunikasi dapat dipahami karena pada dasar bahasa tersebut diungkapkan dalam satuan sintaksis yaitu dari konstituen yang paling dasar berupa klausa dan dapat dilengkapi dengan konjungsi bila diperlukan dan intonasi final (Chaer,2009:44). Dalam film Hafalan Shalat Delisa konstruksi kalimat yang terorganisasi dengan sempurna jarang ditemukan. Kalimat-kalimat dalam film tersebut dibangun oleh sebuah predikat atau subjek saja. Konstruksi tersebut memperlihatkan bahwa bahasa yang digunakan adalah bahasa komunikasi lisan. Padahal, kalimat yang lengkap dan gramatikal adalah kalimat yang memiliki unsurunsur subjek $(\mathrm{S})$, predikat $(\mathrm{P})$, objek $(\mathrm{O})$, pelengkap $(\mathrm{P})$, keterangan $(\mathrm{K})$, konjungsi dan modalitas. Kemunculan setiap konstituen dalam konstruksi bergantung pada predikatnya. Selain kemunculan konstituen tersebut, sebuah kalimat disebut juga sebagai sebuah satuan bahasa yang secara relatif berdiri sendiri, mempunyai pola intonasi final, terdiri atas klausa secara aktual dan potensial; klausa bebas yang menjadi bagian kognitif percakapan; satuan proposisi yang merupakan gabungan klausa atau merupakan satu klausa, yang membentuk satuan bebas; Jawaban minimal, seruan, salam, dan sebagainya (Kridalaksana, 2001).

Penelitian ini difokuskan pada kalimat, karena kalimat merupakan fokus kajian sintaksis. Penelitian bahasa yang menitikberatkan kajian dalam bidang sintaksis sudah banyak dilakukan, terutama kajian yang mengamati konstruksi kalimat. Peneliti yang mengamati konstruksi kalimat sebagian besar menggunakan data yang diambil dari novel, teks tulis, karangan argumentasi, dan wacana iklan (Wijaya, 2020; Wahyuni, 2019; Maharani, 2019; Cahyani, 2018; Nursan, 2016; Zahrulia, 2012; Ayuma, 2012;). Hanya beberapa penelitian yang mengamati konstruksi kalimat berbasis dialog dalam sebuah film sehingga hasil penelitian ini dapat menambah konstruksi pilihan kalimat yang digunakan dalam sebuah dialog film. Film yang dibintangi oleh Reza Rahadian dan Nirina Zubir merupakan film yang mengisahkan keikhlasan dan kesabaran dalam menjalani setiap ujian dan musibah yang diberikan oleh Tuhan Yang Maha Esa pemilik alam semesta beserta isinya. Kisah dalam dialog dikemas dalam bahasa yang cukup mudah dipahami sehingga mudah bagi penelitian mengkaji data bahasa. Selain bahasa yang cukup mudah dipahami, konstruksi kalimay yang sederhana, sarat dengan makna, juga karena bahasa yang 


\section{STILISTIKA}

digunakan adalah bahasa yang umum digunakan dalam sehari-hari yang bercampur dengan bahasa keagamaan. Kebebasan penggunaan berbahasa (licentia poetica) menjadi daya tarik mengkaji diolog film Hafalan shalat Delisa.

Berdasarkan uraian di atas, kajian dalam Hafalan Shalat Delisa ini dilakukan untuk menjawab pertanyaan Bagaimanakah konstruksi kalimat dan ciri bahasa dalam dialog film tersebut? Untuk mengetahui hal tersebut, kajian ini difokuskan pada jenis-jenis kalimat dan analisis tataran sintaksis yang mencakup fungsi, kategori, dan peran sintaksis.

Penelitian yang mengkaji konstruksi kalimat sudah dilakukan oleh beberapa peneliti pada tahun 2012 sampai dengan 2020. Kajian-kajian tersebut berfokus pada teks tulis, wacana iklan, karangan argumentasi siswa, novel, dialog film, surat kabar dan kumpulan berita.

Kajian konstruksi kalimat dilakukan oleh Ayuma (2012) pada Wacana Tulis Di Lembaga Kepolisian Polres Tulang Bawang Lampung. Dalam hasil penelitiannya yang berupa skripsi, dia berhasil mendeskripsikan (1) jenis-jenis kalimat (2) tipe-tipe kalimat, dan (3) hubungan makna antarklausa yang terdapat dalam wacana tulis di lembaga kepolisian Polres Tulang Bawang. Zahrulia (2012) juga mengamati konstruksi kalimat dalam wacana Iklan Brosur Provider Telekomunikasi melalui skripsi yang berjudul "Analisis Struktur Kalimat Pada Wacana Iklan Brosur Provider Telekomunikasi" menghasilkan deskripsi jenis-jenis dan struktur kalimat pada wacana iklan dalam brosur provider telekomunikasi. Nursan (2016) melakukan penelitian yang mengamati konstruksi kalimat pada karangan siswa. Kajian terhadap karangan tersebut dilaporkan dalam tugas akhirnya yang berbentuk skripsi dengan judul "Konstruksi Kalimat Dalam Karangan Mahasiswa Transfer Kredit Yunnan Minzu University (YMU) Di Universitas Negeri Yogyakarta". Nursan menemukan jenis-jenis kalimat berdasarkan jumlah klausa, bentuk konstruksi kalimat, kesalahan konstruksi dalam karangan mahasiswa Yunnan Minzu University (YMU).

Selanjutnya Cahyani (2018) dalam skripsinya yang berjudul "Konstruksi Kalimat pada Teks Iklan Katalog Oriflame" menemukan jenis, struktur dan makna kalimat yang terdapat pada teks iklan katalog Oriflame. Baharuddin (2018) dalam skripsi yang berjudul "Konstruksi Sintaksis pada Novel Sang Pemimpi Karya Andrea Hirata" yang memfokuskan penelitiannya berdasarkan pola kalimat tunggal dan pola kalimat majemuk. Maharani (2019) melakukan penelitian dalam skripsi yang berjudul "Konstruksi Kalimat pada Dialog Film Rumah Tanpa Jendela Karya Aditya Gumay" memfokuskan pada pola kalimat tunggal, kalimat majemuk, jenis kalimat dan makna yang terdapat pada dialog film tersebut. Sama halnya dengan 


\section{STILISTIKA}

penelitian ini, namun yang menjadi pembeda terdapat pada objek kajian dan pada penelitian ini tidak membahas makna namun memfokuskan pada struktur dan jenis kalimat. Wahyuni (2019) dalam jurnal yang berjudul "Analisis Pola, Fungsi, Kategori, dan Peran Sintaksis Pada Kalimat Tunggal Dalam Surat Harian Kompas" yang mendeskripsikan pola kalimat tunggal SPO, SPK dan SPOPelK, serta analisis fungsi, kategori dan peran. Wijaya (2020), dalam skripsi yang berjudul "Konstruksi Kalimat Berfatis dalam Novel Bonsai Hikayat Satu Keluarga Cina Lembahmata Kajian Sintaksis" menjelaskan mengenai struktur kalimat tunggal, majemuk, kalimat deklaratif dan kalimat berfatis.

Dari kajian yang sudah dilakukan, hanya beberapa penelitian yang mengkaji kosntruksi bahasa dalam dialog film. Dengan begitu, belum diketahui begitu mrndalam bagaimana kondisi penggunaan bahasa dalam dialog film. Penelitian ini nantinya akan menggunakan teori struktural. Hal yang sama juga dilakukan oleh peneliti-peneliti sebelumnya. Walaupun demikian, penelitian ini masih bisa dilakukan karena belum ada hasil penelitian yang mengatakan bahwa dialog film Hafalan Shalat Delisa sudah diamati secara linguistik.

Teori struktural dan teori tata bahasa baku bahasa indonesia merupakan dua teori yang digunakan sebagai landasan untuk memecahkan permasalahan dalam mengkaji konstruksi kalimat. Teori struktural merupakan teori yang mengamati bahasa dan hakikat dalam perwujudannya yang konkret sebagai bentuk ujaran. Kajian-kajian yang dilakukan sebelumnya lebih banyak menggunakan teori struktural yang dikemukakan oleh Verhaar (2012:162). Teori Verhaar ini sangat sederhana untuk menganalisis kalimat. Analisis kalimat dilakukan berdasarkan fungsi, kategori dan peran sintaksis. Fungsi sintaksis adalah slot atau gatra yang diisi oleh kata atau satuan lain dalam hubungannya dengan unsur lain dalam kalimat. Fungsi itu bersifat sintaksis, artinya berkaitan dengan urutan kata atau frasa dalam kalimat. Fungsi sintaksis utama dalam bahasa adalah subjek, predikat, objek, pelengkap, dan keterangan.

Chaer (2009:27) menyebutkan bahwa kategori sintaksis adalah jenis atau tipe kata atau frasa yang menjadi pengisi fungsi-fungsi sintaksis. Kategori sintaksis tersebut berkenaan dengan istilah nomina, verba, adjektiva, adverbia, numeralia, preposisi, konjungsi, dan pronomina. Pengisi fungsi tersebut dapat berupa frasa sehingga selain kelas kata yang nomina, terdapat pula frasa nominal. Verhaar (1996) mengatakan, bahwa 'peran' adalah segi semantis dari peserta-peserta verba. Dan unsur-unsur peran ini berkaitan dengan makna gramatikal/sintaksis. Dengan pengisian unsur peran ini, dapatlah diketahui makna yang ada pada masing-masing unsur-unsur fungsional tersebut. Pada dasarnya setiap kalimat memerikan suatu 


\section{STILISTIKA}

peristiwa atau keadaan yang melibatkan satu argumentatau lebih dengan peran tematis yang berbeda-beda. Ada beberapa peran sintaksis yaitu pelaku (aktor), agen, sasaran, pengalaman, peruntung, penerima, penyebab, tema, tetara, hasil, lokasi, alat, tujuan dan sumber (bahan).

Selain fungsi, kategori dan peran sintaksis, juga diamati beberapa jenis kalimat. Jenis-jenis kalimat yang diperkenalkan ada tiga jenis kalimat yaitu (1) kalimat berdasarkan jumlah klausa yang dibagi menjadi dua, kalimat tunggal dan kalimat majemuk, (2) kalimat berdasarkan klasifikasi sintaksisnya dibagi menjadi empat, kalimat deklaratif, kalimat imperatif, kalimat interogatif dan kalimat eksklamatif, (3) kalimat berdasarkan kelengkapan unsurnya, kalimat mmayor (lengkap) dan kalimat minor (tak lengkap).

Pengumpulan data dalam penelitian ini dilakukan dengan menerapkan metode simak. Penggunaan metode simak dibantu dengan teknik lanjutan berupa teknik catat. Fungsi teknik catat adalah untuk mencatat data yang berupa beberapa kalimat-kalimat yang berasal dari dialog film. Hal itu menyebabkan data yang berupa dialog tersebut disimak dan ditranskripsi sehingga dapat menjadi data tulis dialog film.

Setelah data terkumpul, tahapan selanjutnya adalah tahap analisis data. Metode yang digunakan dalam penelitian ini adalah metode agih. Metode agih dalam penelitian ini digunakan untuk menjelaskan struktur kalimat dalam dialog film Hafalan Shalat Delisa. Agar dapat dengan mudah menganalisis data, digunakan eknik dasar berupa teknik bagi unsur langsung (teknik BUL) untuk menentukan fungsi, kategori, dan peran.

Akhirnya, setelah dua tahapan itu dilalui, data disajikan dengan menggunakan metode formal dan informal. Metode formal, yaitu penyajian dengan data-data dan lambang, sedangkan Metode informal adalah rumusan analisis data dengan menggunakan kata-kata biasa (Sudaryanto, 2015:241). Teknik yang digunakan adalah teknik deskriptif.

\section{HASIL DAN PEMBAHASAN}

\section{Struktur Kalimat}

Menurut Verhaar (2012: 162), terdapat tiga cara untuk menganalisis kalimat, yaitu dilihat dari segi fungsi, kategori dan peran sintaksis. Setiap bentuk kata atau frasa yang menjadi konstituen kalimat termasuk dalam kategori kata atau frasa tertentu dan masing-masing mempunyai fungsi sintaksis serta peran semantik. Pada dialog film Hafalan Shalat Delisa terdapat berbagai macam kalimat. Dalam data, ditemukan konstruksi kalimat yang terdiri atas urutan unsur-unsur yang berbeda. 


\section{STILISTIKA}

Konstruksi kalimat sangat beragam dan tidak selalu mengandung kelima fungsi sintaksis. Walaupun demikian, dalam konstruksi tersebut, konstituen pengisi predikat dan subjek selalu hadir. Dari hasil analisis data, diketahui film Hafalan Shalat Delisa dibangun oleh pola kalimat tunggal dan pola kalimat majemuk.

\section{Pola Kalimat Tunggal}

Dialog dalam film Hafalan Shalat Delisa dibangun oleh kalimat tunggal . Hal itu dibukti oleh contoh kalimat (1) yang hanya terdiri atas satu subjek dan satu predikat. Seperti yang disebutkan dalam buku Tata Bahasa Baku Bahasa Indonesia bahwa pola kalimat tunggal merupakan pola paling sederhana dalam bahasa Indonesia karena hanya terdiri atas satu pola kalimat yang mengandung informasi tunggal. Pola kalimat tunggal tidak selalu dalam pola yang pendek, tetapi juga dapat berpola panjang bergantung pada unsur-unsur yang dibutuhkan oleh predikat dalam membangun kalimat tersebut. Secara umum, kalimat tunggal memiliki pola sebagai berikut.

$$
\mathrm{S}+\mathrm{P}+(\mathrm{O})+(\mathrm{Pel})+(\mathrm{K})
$$

Unsur objek, pelengkap, dan keterangan yang ditulis dengan tanda kurung merupakan unsur yang tidak harus selalu hadir atau opsional dan kemunculannya apabila diperlukan. Berikut ini adalah contoh dialog film Hafalan Shalat Delisa.

\section{Pola Kalimat SP}

(1)

$\mathrm{F}:$

"Delisa $\quad \underline{\text { bangun!" }}$

K : Pron V

Peran: Pelaku Statif

(Kamar tidur, $00: 00: 30-00: 00: 31$ )

Kalimat (1) di atas menggambarkan bahwa kalimat dibangun oleh Subjek yang berkategori pronominal Delisa. Konstituen bangun merupakan verba. Masingmasing konstituen menyatakan pelaku yang ditunjukkan pada konstituen Delisa dan keadaan (statif) pada konstituen bangun. Berikut ini adalah contoh konstruksi kalimat yang terdiri atas konstituen subjek, predikat, dan objek.

Pola Kalimat SPO 


\section{"Delisa belum pake kerudung?"}

F : $\quad S$

$\mathrm{P}$

$\mathrm{O}$

K : $\quad$ Pron

FAdv

$\mathrm{N}$

Peran : Pelaku

Statif

Sasaran

(Pekarangan Rumah, $0: 03: 40-0: 03: 43$ )

Pada kalimat (38), fungsi subjek diisi oleh pronominal Delisa yang berperan sebagai pelaku. Fungsi predikat diisi oleh frasa adverbial belum pake yang berperan menyatakan sebuah keadaan atau situasi yang terjadi, kemudian diikuti oleh fungsi objek yang diisi oleh nomina kerudung yang berperan sebagai sasaran.

Pola Kalimat SPK

$\begin{array}{lllc}\text { (386) } & \text { "Delisa } & \text { mau } & \frac{\text { ke dapur umum." }}{\mathrm{K}} \\ \mathrm{F}: & \mathrm{S} & \mathrm{P} & \mathrm{K} \\ \mathrm{K}: & \text { Pron } & \mathrm{V} & \text { FPrep } \\ \text { Peran : } & \text { Pelaku } & \text { Aktif } & \text { Lokasi } \\ \text { (Posko tsunami Aceh, } 1: 10: 56-1: 11: 01)\end{array}$

Berdasarkan kalimat di atas, dapat diketahui bahwa fungsi subjek (386) Delisa diisi oleh pronomina yang berperan sebagai pelaku, sedangkan fungsi predikat diisi oleh verba mau yang berperan menyatakan sebuah tindakan (aktif). fungsi keterangan diisi oleh frasa preporsisi ke dapur uтum. Fungsi keterangan berperan sebagai lokasi karena menyatakan ruang dan/atau waktu terjadinya peristiwa atau proses.

Pola Kalimat SPPel

$\begin{array}{llll}\text { (347) } & \text { "Dia } & \text { kehilangan } & \frac{\text { ibunya" }}{\text { Pel }} \\ \mathrm{F}: & \mathrm{S} & \mathrm{P} & \mathrm{N} \\ \mathrm{K}: & \text { Pron } & \mathrm{V} & \text { Sasaran } \\ \text { Peran : Pelaku } & \text { Statif } & \\ \text { (Posko Pengungsian, } 1: 04: 18-1: 04: 35)\end{array}$

Pada kalimat (347) fungsi subjek diisi oleh pronominal dia yang berperan sebagai pelaku. Fungsi predikat diisi oleh verba kehilangan yang diikuti oleh afiksasi 
ke-/-an serta berperan menyatakan suatu keadaan (statif). Fungsi pelengkap pada kalimat (347) diisi oleh nomina ibunya yang berperan sebagai sasaran.

Pola Kalimat SPOK

\begin{tabular}{|c|c|c|c|c|}
\hline (53) & "Fatimah & pilihin & yang cocok & buat umi." \\
\hline F : & $S$ & $\mathrm{P}$ & $\mathrm{O}$ & $\mathrm{K}$ \\
\hline $\mathrm{K}$ : & Pron & Verba & $\mathrm{FN}$ & FPrep \\
\hline Perar & Pelaku & Aktif & Sasaran & Penerima \\
\hline
\end{tabular}

Pada kalimat (53) diketahui bahwa Fatimah berfungsi sebagai subjek yang merupakan pronominal dan berperan sebagai pelaku. Fungsi predikat pilihin berupa verba yang berasal dari kata pilih kemudian dilengkapi oleh afiks -in dan berperan sebagai tindakan (aktif). yang cocok merupakan fungsi objek yang merupakan frasa nominal yang berperan sebagai sasaran. Tidak lupa juga fungsi keterangan buat umi merupakan frasa nominal yang berperan sebagai penerima.

Pola Kalimat SPOPel

\begin{tabular}{lcccccc}
$(113)$ & “Tiur & ajarin & \multicolumn{2}{c}{ delisa } & \multicolumn{2}{c}{ naik sepeda ya?" } \\
F $:$ & S & P & O & Pel & \\
K : & Pron & & V & Pron & & FV \\
Peran : & Pelaku & Aktif & Sasaran & Tema & \\
(Lapangan, $0: 11: 28-0: 11: 45)$ & & &
\end{tabular}

Berdasarkan contoh di atas dapat diketahui bahwa fungsi subjek diisi oleh pronomina Tiur, serta berperan sebagai pelaku. Fungsi predikat kalimat (113) diisi oleh verba ajarin yang berperan menyatakan suatu tindakan (aktif). Fungsi objek diisi dengan pronominal Delisa yang berperan sebagai sasaran dan fungsi pelengkap pada kalimat diisi oleh frasa verbal naik sepeda ya yang berperan sebagai tema.

Pola Kalimat PK

\begin{tabular}{|c|c|c|}
\hline (410) & "Tidur, & sudah malam!" \\
\hline $\mathrm{F}:$ & $\mathrm{P}$ & K \\
\hline $\mathrm{K}$ : & V & $\mathrm{FN}$ \\
\hline
\end{tabular}


Peran: Statif Tema

(Rumah, $1: 15: 50-1: 15: 51$ )

Berdasarkan contoh di atas, pada kalimat (410) fungsi predikat dibuktikan melalui verba tidur yang berperan menyatakan suatu kedaan (statif) dan pada fungsi keterangan diisi oleh frasa nomina sudah malam yang berperan sebagai tema.

\section{Pola Kalimat PO}

$\begin{array}{lll}(84) & \text { "Lihat } & \text { ade kamu!" } \\ \mathrm{F}: & \mathrm{P} & \mathrm{O} \\ \mathrm{K}: & \mathrm{V} & \mathrm{FN} \\ \text { Peran : } & \text { Tema } & \text { Sasaran } \\ \text { (Pekarangan Rumah, } 0: 07: 31-0: 07: 32)\end{array}$

Berdasarkan ketiga contoh kalimat di atas, kalimat (84) pada fungsi predikat diisi oleh verba lihat yang berperan sebagai tema, sedangkan fungsi objek diisi oleh frasa nominal ade kamu yang berperan sebagai sasaran.

\section{Pola Kalimat Majemuk}

$$
\begin{aligned}
& \mathrm{S} 1+\mathrm{P} 1+\mathrm{O} / \mathrm{Pel} / \mathrm{K}+\mathrm{Kt} \text { Hubung }+\mathrm{S} 2+\mathrm{P} 2+ \\
& \mathrm{O} / \mathrm{Pel} / \mathrm{K}
\end{aligned}
$$

Pada pola di atas dapat diketahui bahwa kedua klausa umumnya setara. Klausa satu bukan merupakan bagian dari klausa lainnya karena kedua kalusa mempunyai kedudukan yang sama dan dihubungkan oleh konjungtor. Berbeda dengan kesatuan yang bersifat koordinatif, kesatuan yang bersifat subordinatif terjadi jika suku kalimat yang satu terikat pada suku kalimat lain dan keterikatan antarsuku dihubungkan oleh kata hubung (konjungsi). Berdasarkan uraian di atas, dapat diketahui bahwa antarklausa dapat memiliki hubungan yang setara dan juga bertingkat. Berikut ada beberapa tipe kalimat yang ditemukan pada dialog film hafalan shalat delisa adalah sebagai berikut. 
Pola Kalimat Majemuk Setara SP + SP

\begin{tabular}{lcccccc}
$(427)$ & “Aku & $\underline{\text { menangis }}$ & & karena & $\underline{a k u}$ & \multicolumn{2}{c}{ sedih." } \\
F : & $\mathrm{S}$ & $\mathrm{P}$ & & Konj & $\mathrm{S}$ & $\mathrm{P}$ \\
$\mathrm{K}:$ & Pron & $\mathrm{V}$ & & Kt Tugas & Pron & $\mathrm{V}$ \\
Peran : & Pelaku & Aktif & & Penjum & Sasasran & Statif
\end{tabular}

(Posko pengungsian, $1: 19: 06-1: 19: 15$ )

Berdasarkan kalimat (11) di atas, dapat dilihat bahwa kalimat tersebut terdiri atas fungsi yang berpola $\mathrm{S}+\mathrm{P}+\mathrm{S}+\mathrm{P}$ dan merupakan kalimat majemuk setara karena setiap unsur memiliki kesetaraan. Kalimat (427) terdiri atas dua klausa yang mempunyai kedudukan yang sama. Kalimat tersebut terdiri atas dua klausa yang dihubungkan oleh konjungtor dan. Klausa pertama yang berada sebelum kata penghubung yang terdiri atas fungsi subjek yang diisi oleh pronominal aku yang berperan sebagai pelaku. Fungsi predikat pada kalimat ini diisi oleh verba menangis, berawal dari kata tangis yang dikuti oleh imbuhan me- dan berperan menyatakan sebuah tindakan atau aktivitas. Lalu pada klausa kedua, terdiri atas fungsi subjek dan predikat. Fungsi subjek pada awal kalimat diawali dengan konjungtor dan. Fungsi subjek diisi oleh pronominal aku yang berperan sebagai sasaran, sedangkan pada fungsi predikat diisi oleh verba sedih yang berperan menyatakan suatu keadaan (statif).

Pola Kalimat Majemuk Bertingkat Konj + SPO + KSP

(81) "Kalo Delisa nggakhapal bacaan shalatnya, nanti umi ambil lagi!"

\begin{tabular}{|c|c|c|c|c|c|c|c|}
\hline $\mathrm{F}:$ & Konj & $S$ & $\mathrm{P}$ & $\mathrm{O}$ & $\mathrm{K}$ & $S$ & $\mathrm{P}$ \\
\hline $\mathrm{K}:$ & Kt Tgs & Pron & $\mathrm{FV}$ & $\mathrm{FN}$ & $\mathrm{N}$ & Pron & $\mathrm{FV}$ \\
\hline Peran : & & Pelaku & Statif & Sasaran & & Tema & Pelaku \\
\hline
\end{tabular}

Aktif

(Pekarangan Rumah, $0: 07: 04-0: 07: 14$ )

Berdasarkan contoh diatas, terdapat dua klausa dalam kalimat ini. Diawali dengan konjungsi kalo atau sama dengan kalau yang merupakan penanda sebuah kalimat majemuk bertingkat, lalu diikuti oleh klausa pertama yang terdiri atas subjek, predikat dan objek, sedangkan pada kalusa kedua terdiri atas fungsi 


\section{STILISTIKA}

keterangan, subjek dan predikat. Klausa pertama terdiri atas fungsi subjek yang diisi oleh pronominal Delisa yang berperan sebagai pelaku. Pada fungsi predikat diisi oleh frasa verba nggak hapal yang berperan menyatakan suatu keadaan (statif) dan pada fungsi objek diisi oleh frasan nominal bacaan shalatnya berperan sebagai sasaran. Pada klausa kedua hanya terdiri atas fungsi keterangan, subjek dan predikat. Fungsi keterangan diisi oleh nomina nanti yang berperan sebagai tema. Pada fungsi subjek, diisi oleh pronominal umi yang berperan sebagai pelaku, sedangkan fungsi predikat diisi oleh frasa verbal ambil lagi yang berperan menyatakan suatu tindakan (aktif).

\section{JENIS-JENIS KALIMAT}

Setiap kalimat selalu mengandung dua unsur yang saling mengisi. Bagian yang saling mengisi itu harus memiliki pengertian yang dapat diterima secara logis. Selalu ada yang dikemukakan diikuti oleh bagian yang menerangkan ataupun memberikan sesuatu tentang yang dikemukakan. Bagian yang dikemukakan dalam bahasa disebut dengan subjek dan bagian yang menerangkan disebut predikat.

\section{Jenis Kalimat Berdasarkan Jumlah Klausa pada Dialog Film Hafalan Shalat Delisa.}

Berdasarkan jumlah klausanya, kalimat dapat dibedakan menjadi dua yaitu kalimat tunggal dan kalimat majemuk. Kalimat majemuk dibagi menjadi tiga yaitu kalimat majemuk setara, kalimat majemuk bertingkat dan kalimat majemuk campuran. Keempat jenis kalimat tersebut ditemukan pada dialog film Hafalan Shalat Delisa yang dapat diurailan sebagai berikut.

\section{Kalimat Tunggal}

"Kak sofi juga ikut?" kalimat (418) tersebut berpola S-P, yang diketahui bahwa tipe ini merupakan salah satu pola kalimat tunggal. Kalimat ini terdiri atas fungsi subjek yang diisi oleh frasa pronominal kak sofi dan diikuti oleh predikat yang diisi oleh frasa adverbial juga ikut. "Kamu tidak kangen mereka?" berdasarkan kalimat tersebut berpola S-P-Pel, diketahui bahwa fungsi subjek diisi oleh pronominal kamu. Fungsi predikat kalimat tunggal diisi oleh frasa verbal tidak kangen yang diikuti oleh pelengkap yang diisi oleh pronominal mereka.

\section{Kalimat Majemuk Setara}




\section{STILISTIKA}

Kalimat majemuk setara merupakan kalimat yang terdiri atas dua klausa atau lebih yang memiliki hubungan atau kedudukan yang setara. Hubungan antar klausa itu dapat ditandai dengan adanya unsur konjungsi dan, atau, tetapi, serta, lagipula, sedangkan, melainkan dan lain-lain. Karena klausa-klausa dalam kalimat majemuk disusun dengan cara koordinasi yang mempunyai kedudukan setara atau sama, klausa-klausa itu semuanya merupakan klausa utama (Alwi dkk., 2003:387). Ada beberapa contoh yang ditemukan yaitu sebagai berikut.

"Gua punya tawaran dan kasih paruh harga". Kalimat (69) terdiri atas dua predikat, yaitu frasa verba punya tawaran dan verba kasih yang dihubungkan dengan konjungtor dan. "Sudah hapal kok tapi delisa masih suka salah hehe". Pada kalimat (168) dihubungkan oleh konjungtor tapi. Kalimat (168) terdiri atas dua frasa adverbial dan klausa verbal yaitu sudah hapal kok dan delisa masih suka salah hehe.

\section{Kalimat Majemuk Bertingkat}

Hubungan antar klausa itu dapat ditandai dengan adanya unsur konjungsi ketika, saat, sehingga, jika, kalau, apabila dan lain-lain. Terdapat beberapa contoh kalimat majemuk bertingkat yang ditemukan yaitu sebagai berikut.

"Kan kamu sudah janji kalau tidak masuk kamu jadi kiper." berdasarkan kalimat tersebut dapat diketahui bahwa kalimat tersebut merupakan kalimat majemuk bertingkat. Hal ini ditandai oleh bagian kalimat yang didahului kata penghubung disebut anak kalimat atau klausa subordinatif, sedangkan bagian sebelumnya disebut klausa utama atau induk kalimat. Pada kalimat (112) terlihat bahwa klausa utama kamu sudah janji dihubungkan dengan klausa subordinatif tidak masuk kamu jadi kiper dengan menggunakan konjungtor kalau. Dalam kalimat (112) klausa utama pada fungsi subjek diisi oleh pronominal kamu dan fungsi predikat diisi oleh frasa verbal sudah janji. Klausa subordinatif pada fungsi predikat diisi oleh frasa verbal tidak masuk, fungsi subjek diisi oleh pronominal kamu dan fungsi pelengkap diisi oleh frasa nomina jadi kiper.

\section{Kalimat Majemuk Campuran}

Kalimat majemuk campuran merupakan kalimat majemuk gabungan antara kalimat majemuk setara dengan kalimat majemuk bertingkat. Adapun beberapa contoh kalimat majemuk campuran adalah sebagai berikut. 
"Dia meminta aku menjemput-nya di sekolah tapi sepertibiasa aku tidak bisa menjemputnya sehingga ibunya yang pergi menjemputnya. Pada kalimat (265) ini terdiri atas kalimat majemuk setara dan kalimat majemuk bertingkat. Kalimat majemuk setara ditandai oleh konjungtor tapi yang merupakan penghubung perlawanan dan kalimat majemuk bertingkat yang ditandai dengan konjungtor sehingga.

\section{JENIS KALIMAT BERDASARKAN KLASIFIKASI SINTAKSIS PADA DIALOG FILM HAFALAN SHALAT DELISA}

Berdasarkan klasifikasi sintaksisnya, dapat dibedakan menjadi empat jenis yaitu, kalimat deklaratif, imperatif, interogatif dan eksklamatif yang diuraikan sebagai berikut.

\section{Kalimat Deklaratif}

Kalimat deklaratif atau yang biasa disebut dengan kalimat berita pada umumnya digunakan oleh pembicara atau penulis untuk membuat suatu pernyataan yang isinya berupa berita bagi pendengar maupun pembaca.

"Warna ungu itu bikin wajah menjadigelap." Berdasarkan penjelasan di atas, kalimat (51) merupakan sebuah kalimat deklaratif. Hal ini dibuktikan oleh adanya informasi atau berita yang terdapat pada kalimat tersebut. Informasi yang terdapat dalam kalimat tersebut meliputi warna ungu itu bikin wajah menjadi gelap pada kalimat (51), frasa adjektiva menjadi gelap didahului oleh prefiks meN- yang membentuk kata kerja aktif.

\section{Kalimat Imperatif}

Kalimat imperatif atau yang biasa disebut kalimat perintah umumnya dapat berupa suruhan, larangan, permohonan, ajakan dan lain-lain. Kalimat imperatif dibagi menjadi dua yaitu, kalimat imperatif tak transitif dan kalimat imperatif transitif.

“Ambil cepat!". Pada kalimat (35), kalimat imperatif ditandai oleh kehadiran verba dasar pada awal kalimat. Verba dasar ambil pada kalimat (35) merupakan predikat yang mengandung makna inheren perbuatan dan dapat digunakan pada kalimat imperatif. "Siapkan kamar operasi!". Dilihat berdasarkan segi ketransitifannya, kalimat (247) merupakan kalimat imperatif transitif 


\section{STILISTIKA}

(memerlukan objek). Pada kalimat (247) ditandai oleh kehadiran sufiks -kan pada kalimat siapkan kamar operasi! berfungsi membentuk kalimat perintah, tanpa adanya sufiks -kan maka kalimat tersebut bukanlah kalimat imperatif. Kalimat imperative ditandai oleh hadirnya verba siapkan yang mengandung makna perbuatan yang dilengkapi oleh frasa nomina kamar operasi sebagai objek yang melengkapi kalimat imperatif transitif ini.

\section{Kalimat Interogatif}

Kalimat interogatif merupakan sebuah kalimat pertanyaan yang pada umumnya ditandai dengan kata tanya apa, siapa, berapa, kapan, bila, bagaimana, dan di mana yang biasanya diikuti dengan atau tanpa partikel - kah sebagai penegas dan diakhiri oleh intonasi akhir tanda tanya. Berikut ini merupakan beberapa contoh yang ditemukan sebagai berikut.

“Kenapa ya delisa susah bangun?". Berdasarkan contoh tersebut terlihat bahwa kedua kalimat interogatif tersebut ditandai oleh adanya kata penanya kenapa dan kok yang diakhiri oleh intonasi akhir berupa tanda tanya (?). Kata kenapa pada kalimat (19) menjadikan kalimat berita menjadi kalimat tanya. " Kalimat tersebut ditandai oleh adanya kata penanya gimana pada kalimat (95) dan diakhiri oleh intonasi akhir berupa tanda tanya (?). kata penanya gimana merupakan bentuk tidak baku dari kata penanya bagaimana, kata ini berfungsi mengubah kalimat pernyataan menjadi kalimat tanya.

\section{Kalimat Eksklamatif}

Kalimat eksklamatif secara formal ditandai oleh kata alangkah, betapa, atau bukan main pada kalimat berpredikat adjektiva. Kalimat ini merupakan kalimat yang menuatkan emosi, seperti karena kaget, kagum, takjub, terkejut, heran, marah, sedih, gemas, kecewa, tidak suka, dan sebagainya yang dapat diuraikan sebagai berikut.

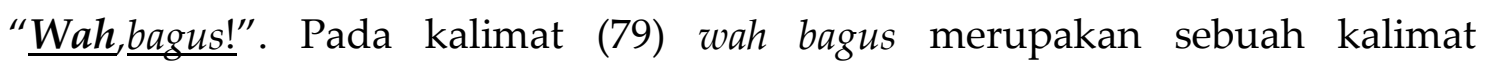
eksklamatif yang dibuktikan melalui kata wah yang berarti kagum akan sesuatu.

\section{Jenis Kalimat Berdasarkan Kelengkapan Unsurnya pada Dialog Film Hafalan Shalat Delisa}




\section{STILISTIKA}

Berdasarkan kelengkapan unsurnya dapat dibedakan menjadi dua jenis, yaitu kalimat lengkap (mayor) dan kalimat tidak lengkap (minor) yang dapat diuraikan sebagai berikut. Adapun beberapa contoh yang ditemukan adalah sebagai berikut.

\section{Kalimat Lengkap}

Kalimat lengkap (kalimat mayor) bisa berupa kalimat dasar atau kalimat luas yang memiliki unsur S-P, S-P-O, S-P-O-Pel, S-P-O-Ket dan sebagainya. " Kamu pasti akan mendapatkannya!". Pada kalimat (100) terdapat fungsi subjek kamu dan predikat pasti akan mendapatkannya yang berupa frasa verba dan tidak terdapat fungsi objek namun kalimat tersebut telah cukup menjadi satu kesatuan yang sekurangkurangnya terdiri atas unsur S-P.

\section{Kalimat Tidak Lengkap}

Kalimat tidak lengkap (kalimat minor) merupakan kalimat yang unsurunsurnya tidak lengkap. Kalimat tidak lengkap pada dasarnya terdiri atas sebuah klausa terikat, atau sama sekali tidak mengandung struktur klausa. Berikut merupakan contoh kalimat tidak lengkap adalah sebagai berikut.

“Tidak boleh berharap terlalu banyak tau!". Berdasarkan kalimat tersebut, kalimat (47) merupakan kalimat tak lengkap. Hal ini ditandai oleh ketidakhadiran subjek dan predikat di dalamnya. Pada kalimat (47) tidak boleh berharap terlalu banyak tau! berpola P-K yang merupakan klausa verbal dan tidak adanya fungsi subjek yang membuat kalimat ini menjadi kalimat yang tidak lengkap.

\section{SIMPULAN}

Berdasarkan hasil penelitian dan pembahasan mengenai konstruksi kalimat pada dialog film Hafalan Shalat Delisa dapat ditarik beberapa kesimpulan yaitu, struktur kalimat tunggal terdiri atas delapan pola yaitu, S-P, S-P-O, S-P-K, S-P-Pel, SP-O-K, S-P-O-Pel, P-K, dan P-O. Struktur kalimat majemuk terdiri atas lima pola yaitu, pola kalimat majemuk setara $\mathrm{SP}+\mathrm{SP}$, pola kalimat majemuk setara $\mathrm{SP}+\mathrm{PO}$, pola kalimat majemuk setara $\mathrm{SP}+\mathrm{PK}$, pola kalimat majemuk bertingkat Konj+SPO+KSP, dan pola kalimat majemuk setara SPPel+SPO. Jenis-jenis kalimat yang ditemukan pada dialog film Hafalan Shalat Delisa terdiri atas kalimat berdasarkan jumlah klausanya, kalimat berdasarkan klasifikasi sintaksisnya dan kalimat berdasarkan kelengkapan unsurnya. Jenis kalimat berdasarkan jumlah klausanya terdiri atas kalimat tunggal, kalimat majemuk setara, kalimat majemuk majemuk bertingkat dan 


\section{STILISTIKA}

kalimat majemuk campuran. Jenis kalimat berdasarkan klasifikasi sintaksisnya terdiri atas kalimat deklaratif (kalimat berita), kalimat imperatif (kalimat perintah), kalimat interogatif (kalimat tanya) dan kalimat eksklamatif. Jenis kalimat berdasarkan kelengkapan unsurnya terdiri atas kalimat lengkap dan kalimat tidak lengkap.

Penelitian tentang analisis kalimat pada dialog film Hafalan Shalat Delisa ini masih sangat sederhana dan banyak kekurangan didalamnya untuk diketahui lebih lanjut. Masih banyak permasalahan-permasalahn sintaksis khususnya masalah kalimat yang belum diteliti. Oleh karena itu, perlu dilakukan penelitian lebih lanjut mengenai analisis kalimat pada dialog film Hafalan Shalat Delisa.

\section{UCAPAN TERIMA KASIH}

Puji dan syukur penulis sampaikan ke-hadirat Tuhan Yesus Kristus atas berkat dan Kuasa-Nya jurnal ini dapat penulis selesaikan dengan baik. Penulis menyampaikan terima kasih yang sebesar-besarnya kepada Dr. Made Sri Satyawati, S.S., M.Hum. dan Dr., Drs. Anak Agung Putu Putra, M.Hum., selaku pembimbing skripsi penulis yang telah sabar dan bersedia meluangkan waktu untuk membimbing penulis. Ucapan terima kasih juga penulis sampaikan kepada Seluruh Dosen Program Studi Sastra Indonesia, Fakultas Ilmu Budaya, Universitas Udayana atas segala ilmu dan pengetahuan yang telah diberikan kepada seluruh mahasiswa dalam menempuh pendidikan di lingkungan Fakultas Ilmu Budaya. Tak luput juga penulis ucapkan terima kasih kepada keluarga tercinta, almahrum bapak Drs. S. Butarbutar, ibu K. br Nababan, serta kedua adik penulis Charel Stefanus dan Christian Jeremy, yang selalu memberikan dukungan, doa, kasih sayang, perhatian dan motivasi, baik secara moral maupun finansial sehingga penulis dapat menyelesaikan skripsi ini

\section{DAFTAR PUSTAKA}

Alwi, Hasan, dkk.. 2003. Tata Bahasa Baku Bahasa Indonesia. Jakarta: Balai Pustaka.

Ayuma, Wiwik Yuni. 2012. Konstruksi Sintaksis Pada Wacana Tulis di Lembaga Kepolisian Polres Tulang Bawang Lampung (skripsi). Yogyakarta: Program Studi Bahasa dan Sastra Indonesia Fakultas Bahasa dan Seni, Universitas Negeri Yogyakarta. (PDF)

Baharuddin, Nurhaemi. 2018. Konstruksi Sintaksis pada Novel Sang Pemimpi Karya Andrea Hirata (skripsi). Makassar: Program Studi Pendidikan Bahasa dan Sastra 
Indonesia Fakultas Keguruan dan Ilmu Pendidikan, Universitas Muhammadiyah Makassar. (PDF)

Chaer, Abdul. 2008. Morfologi Bahasa Indonesia (Pendekatan Proses). Jakarta: PT. Rineka Cipta.

Chaer, Abdul. 2009. Sintaksis Bahasa Indonesia (Pendekatan Proses). Jakarta: Rineka Cipta.

Cahyani, I Gusti Ayu Intan. 2018. Konstruksi Kalimat pada Teks Iklan Oriflame (skripsi). Denpasar: Program Studi Sastra Indonesia Fakultas Ilmu Budaya, Universitas Udayana.

Kridalaksana, Harimurti. 2001. Kamus Linguistik. Jakarta: Gramedia Pustaka Utama. Kushartanti, dkk (ed). 2005. Pesona Bahasa. Jakarta: Gramedia. (PDF)

Maharani, Ni Made Sri. 2019. Konstruksi Kalimat pada Dialog Film Rumah Tanpa Jendela Karya Aditya Gumay (skripsi). Denpasar. Program Studi Sastra Indonesia Fakultas Ilmu Budaya, Universitas Udayana.

Nursan, Demanda Ridhawaty. 2016. Konstruksi Kalimat dalam Karangan Mahasiswa Transfer Kredit Yunnan Minzu University (YMU) di Universitas Negeri Yogyakarta (skripsi). Yogyakarta: Program Studi Pendidikan Bahasa dan Sastra Indonesia Fakultas Bahasa dan Seni, Universitas Negeri Yogyakarta. (PDF)

Ramlan. 1996. Ilmu Sintaksis. Bandung: CV. Karyono. (PDF)

Rinanda, Zahrulia Arina. 2012. Analisis Struktur Kalimat Pada Wacana Iklan Brosur Provider Telekomunikasi (skripsi). Yogyakarta: Program Studi Bahasa dan Sastra Indonesia Fakultas Bahasa dan Seni, Universitas Negri Yogyakarta. (PDF)

Sudaryanto. 2015. Metode dan Aneka Teknik Analisis Data: Pengantar Penelitian Wahana Kebudayaan secara Linguistis. Yogyakarta: Sanata Dharma.

Verhaar, J.W.M. 2012. Asas-Asas Linguistik Umum. Yogyakarta: Gajah Mada Univerity Press

Wahyuni, Rina Tri. 2019. “Analisis Pola, Fungsi, Kategori dan Peran Sintaksis Pada Kalimat Tunggal Dalam Surat Kabar Harian Kompas". Bahtera: Jurnal Pendidikan, Bahasa, Sastra dan Budaya, Jilid 06 no. 12.

Wijaya, Handi. 2020. Konstruksi Kalimat Berfatis dalam Novel Bonsai Hikayat Satu Keluarga Cina Lembahmata Kajian Sintaksis"(skripsi). Bandung: Program Studi Sastra Indonesia Fakultas Ilmu Budaya, Universitas Padjajaran. (PDF).

\section{PROFIL PENULIS}

Puronami Sarah Stefany merupakan mahasiswa Program Studi Sastra Indonesia angkatan tahun 2017. Pada tahun 2017, pernah menjadi anggota bidang kominfo Himpunan Mahasiswa Sastra Indonesia. Pada tahun 2018, pernah menjadi koordinator karya seni pada Himpunan Mahasiswa Sastra Indonesia. Pada tahun 2020 pernah menjadi anggota bidang 1 Badan Perwakilan Mahasiswa Fakultas Ilmu Budaya. 
Dr. Made Sri Satyawati, S.S., M.Hum. mendapat gelar sarjana (S1) pada Program Studi Bahasa dan Sastra Indonesia Fakultas Sastra Universitas Udayana tahun 1993. Karena mendapat beasiswa Tunjangan Ikatan Dinas, tahun 1994 diangkat menjadi dosen tetap di almamaternya. Tahun 1997 melanjutkan studi S2 di Jurusan Ilmu-Ilmu Sastra Universitas Padjadjaran Bandung dan menyelesaikan studi tahun 1999. Pada tahun 2004 melanjutkan studi S3 di Program Studi Ilmu Linguitik Pascasarjana Universitas Udayana dan menyelesaikan studinya tahun 2010. Menjabat sebagai sekretaris Program Studi Ilmu Linguistik PPs Unud tahun 2011 sampai 2014. Menjabat sebagai Sekretaris Program S3 Ilmu Linguistik dari tahun 2016 s.d. 2017. Mulai tahun 2018 menjabat sebagai Ketua Program S2 Ilmu Linguistik Universitas Udayana sampai sekarang. Sejak 2019--2023 menjabat Dekan FIB Universitas Udayana.

Dr. Drs. Anak Agung Putu Putra, M.Hum. mendapat gelar sarjana pada tahun 1985 di Program Studi Bahasa dan Sastra Indonesia Fakultas Sastra Universitas Udayana dengan skripsi berjudul "Bahasa Sasak di daerah Kabupaten Lombok Timur: Sebuah Tinjauan Geografi Dialek". Gelar magister diperoleh pada Program Linguistik, Program Pascasarjana Universitas Hasanuddin pada tahun 1993 dengan judul tesis "Konstruksi Oblik Bahasa Bali: Analisis Transformasi Generatif". Pada tahun 2007 berhasil menyelesaikan Program Doktor, Program Pascarsarjana Universitas Udayana dengan disertasi berjudul "Segmentasi Dialektal Bahasa Sumba di Pulau Sumba: Suatu Kajian Dialektologi”. Menjabat Ketua Jurusan Sastra Indonesia Fakultas Sastra Universitas Udayana tahun 2009 s.d. 2012. Pada tahun 2012 s.d 2016 menjabat sebagai sekretaris Program Doktor Program Pascasarjana Universitas Udayana. Sampai saat ini masih aktif sebagai tenaga pengajar di Program Sarjana, Program Magister, dan Program Doktor Fakultas Ilmu Budaya Universitas Udayana. 